\title{
Reviews
}

\author{
Feather, John; Matthews, Graham; Eden, Paul
}

Preservation management: policies and practices in British libraries. Aldershot: Gower, 1996. $£ 40.00$ (ISBN 0-566-07622-5).

\author{
PETER FOX \\ University Librarian \\ Cambridge University Library
}

The 1984 report of the Cambridge University Library Conservation Project, which has subsequently become known as the Ratcliffe Report, undoubtedly marked a turning point in preservation activity in libraries in the United Kingdom. Conservation had, up to that time, been an arcane process almost exclusively confined to archives and rare books departments. Since that time there has been an ever-growing awareness that preservation is a more wide-ranging concept and one that must be espoused by any librarian responsible for a collection which is other than purely ephemeral.

The Ratcliffe report was based upon a survey of practices and attitudes in British libraries in the early 1980 s. The book presently under review is based upon a similar survey, carried out ten years later with the intention of establishing what developments had taken place in the intervening decade.

It begins with a detailed review of 'a decade of development' covering areas such as awareness raising, education and training, preservation policy, disaster management, substitution and 'hands-on' conservation. It notes that the role of the National Preservation Office, the creation of which was a direct outcome of the Ratcliffe Report, has been a major factor in awareness-raising.

The book then goes on to look in more detail at perceptions of preservation, preservation in practice, priorities, and policies. Each chapter is based upon an analysis of the questionnaires and frequently includes direct quotations from respondents, which undoubtedly play a major role in enlivening the text and increasing its relevance for the practising librarian. Each chapter is also equipped with an extensive list of references. These are valuable and would have been considerably more so had it not been for the authors' infuriating predilection for references of the type 'Bloggs op.cit., p.x', which require the reader to plough back through hundreds of references in earlier chapters to find the first appearance of 'Bloggs'. 
The report concludes that there is undoubtedly a greater awareness of preservation issues than there was ten years ago but that this perception is not always a positive one and, certainly, the report does not encourage complacency. Given the scale of the problem of decaying collections, it identifies the need for a national retention policy as the key issue now to be addressed. Retention, as the authors point out, implies preservation. No one library, or even one sector, can hope (or be expected) to undertake the burden of retention and preservation on a national scale. It is a problem which affects national, academic, public and special libraries, at different levels and in different ways, and, given the variety of funding agencies for those different sectors it is difficult to identify where such a policy might be developed. At a strategic level, the Library and Information Commission has a wider brief than any other body, and at a more practical level, the role of the National Preservation office is crucial, especially now that it is funded by a consortium consisting of the British Library, the Public Record Office, the legal deposit libraries, and the Consortium of University Research Libraries (CURL).

This book is an important contribution to the development of preservation as an integral part of library management. Though it is, fundamentally, the report of a piece of research, the authors' deep knowledge of the subject has turned what might have been a factual, statistical survey into an extremely valuable - and, to this reviewer, surprisingly practical - study of preservation management. It covers not just the strategic, national issues, in which, inevitably, relatively few are involved, but also includes practical guidance on preservation planning in the individual library. I would recommend it to anyone responsible for maintaining, thinking of producing, or feeling they ought to prepare, a preservation policy for their own collections.

\section{Jordan, Peter}

Staff management in library and information work. 3rd. ed. Aldershot: Gower, 1995. £42:50 (ISBN 0-566-07581-4).

\section{Anne Goulding \\ University of Loughborough}

This is the third edition of this valuable book, which has become a core text for both students in departments of information and library and practising librarians in supervisory positions. The secret of its success lies in the approach which mixes practical advice and examples with theory and up-to-date research in the field. This new edition omits the exercises that previous editions included at the end of chapters to test the reader's knowledge, but includes many more illustrations of best practice.

Jordan moves from consideration of broad concepts and issues around the management of people to the nitty gritty of techniques and methods. The first chapter outlines the huge changes that have taken place in the working environment generally, and the library workplace in particular, which make a new edition of this text so necessary. Changes that have taken place in technology, education, the economy, and the political situation since the previous edition in 1987 are all discussed here. The effects of change in the economic and political environment on the management of library and information services (LIS) are particularly striking. In 1987 these issues hardly rated a mention in the introductory chapter, apart from a few pointed comments about staffing shortages and no-growth budgets. In contrast, the new edition devotes a whole section to 
restructuring, income generation, $\mathrm{CCT}$, quality, the charter movement and customer consultation, all of which demonstrate how crucial it is that today's LIS manager is a political animal as well as technically competent. Another sign of the times is the omission of a section in the previous edition which traced the growing influence of trades unions in the professions throughout the 1970s, although by 1987 they were probably already past their heyday. The chapter closes with a summary of important employment legislation with which LIS managers should be familiar.

Little has changed in the chapter on 'Motivation and Job Satisfaction', which remains an excellent summary of theory and research in this area. Jordan takes the reader chronologically through the work of the main motivation theorists and relates these to the LIS field, outlining how the theories of how and why people are motivated at work can be used practically to design jobs that are potentially more satisfying. Job design and participative management are discussed but Jordan warns of the danger of regarding these as panaceas for low morale or poor motivation and also points out the limitations of motivation theories, accusing their proponents of making the generalisation that work is the main source of satisfaction in everybody's life. Thus, although attempts at job design might have the best humanitarian, as well as operational, intentions, Jordan suggests that any bid to improve the quality of worklife for staff should be undertaken with the utmost care and with full involvement of those affected.

The chapter entitled 'Manpower Planning' in the 1987 edition has been 'gender-neutralised' and renamed 'Workforce Planning'. This chapter moves from a general consideration of the changing nature of the information workforce as a whole, to the more immediate issues facing library managers when deciding the composition of their staff. Various reports of the 1980s on the supply and demand of information workers for the future are considered and summarised, along with the views of employers. Jordan reports that public library employers, in particular, were disappointed with the quality of new recruits to the profession but until the number of graduate traineeships and full-time career posts at a junior level expand, it is unlikely that enthusiasm for public library work among the best young professionals will be stirred. An interesting point taken up is that made by a British Library study on the education and recruitment of junior professionals ${ }^{(1)}$ which suggests that as departments of information and library studies become more IT focused in response to the changing market, so they ought to attract better quality candidates, notably men, who had hitherto been discouraged by the bookish and rather dull image of 'librarianship'. Thus, the feminization hypothesis ${ }^{(2)}$ raises its head once more with the contention that the low status and relatively low pay of the profession is due to the numerical dominance of women and that, to raise the status of the profession, members must turn to IT and science in the belief that information science carries with it the status (and masculinity) of a 'hard' subject.

The remainder of this chapter outlines workforce planning in the individual library, covering analysis of existing staff, wastage rates, forecasting demand, and balancing supply and demand. The 1987 edition concentrates on staff cuts and restructuring while the new edition, in contrast, draws the reader's attention to the imminent detonation of the demographic timebomb as staff shortages loom again. Flexible working practices are advocated as a way of recruiting and retaining those with caring responsibilities, particularly women.

Chapters Four and Five consider the practicalities of how library managers can obtain the quantity and quality of staff they have described in their workforce plan. Chapter Four covers job description and personnel specification and presents a number of up-to-date examples in various sectors and suggests practical methods of carrying out both job analysis and description. Similarly, the down-to-earth advice on how to construct a personnel specification is accompanied by examples illustrating good practice. 
Chapter Five moves on to consider the selection of staff, beginning with the job advertisement and moving on to shortlisting before concentrating on selection methods and particularly the interview. The chapter is, again, very practical, giving almost step-by-step instructions for exemplary recruitment and selection practice. Although much of the advice is common sense, someone new to interviewing would find the straightforward advice and use of examples an invaluable source. Surprisingly few supervisors have formal training in the art of interviewing, most relying on their experience of being interviewed. This chapter would guide even the most inexperienced through their first interview as interviewer. It would also be a-useful read for those preparing to be interviewed, as it gives an insight into the techniques and communication strategies used by selectors.

Having acquired the necessary staff, the library manager then needs to ensure that the best is made of their skills and talents, and so Jordan moves on to consider staff appraisal in chapter Six and training and development in chapter Seven. Much of chapter six has been rewritten because, whereas in 1987 space was devoted to explaining why appraisal systems were not used more in UK LIS, in 1995 Jordan outlines why the picture today is very different. For public libraries, Jordan cites the influence of the "Conservative Government's managerialist philosophy", to which I would add the quest for the Investors in People award. Jordan suggests, though, that the difference is most marked in academic libraries and considers the Jarratt Report most crucial in this respect. Once again, straightforward, practical advice on how to approach appraisal is given, including recommendations about who should do the appraising and explanations of the different types of procedures supervisors might encounter.

The chapter on training and development takes the reader through all the stages of the training cycle from identifying training needs to evaluation of training. The distinction is made between training and development, the former identified as the imparting of specific skills necessary to the individual's job, the latter perceived as a much more open concept related to awareness, outlook and perspective. To bring this new edition up to date Jordan gives accounts of S/NVQs and the LA's Framework for Continuing Professional Development. The main steps a library manager should take when preparing a training programme are clearly set out and useful descriptions of training methods are given with examples and illustrations. The section on staff development takes less of a 'how-to-do-it' approach, and instead reviews some of the important developments and issues in this area including benchmarking.

The final chapter sees a return to management theory but manages to extract valuable supervisory lessons and practical pointers from the research on management styles, leadership and organizational conflict. This chapter has been expanded considerably, which reflects the increasing importance with which employers regard staff supervision and interpersonal skills - the focus of this chapter. The enlargement of this chapter also reflects the increase in research and study in this area. The chapter covers what being a supervisor entails, including coping with the difficult member of staff, and then continues to consider leadership, managing a group, assertiveness training, transactional analysis, managing stress and time management. Although the theory in all these areas are covered, it is also very practical, with self-evaluative tools and checklists for readers to monitor their own eg workaholism rating. The reorganisation and additions to this chapter are well thought out and useful, providing beginning (or more experienced) supervisors with valuable tips in this very important aspect of staff management. 
The one discordant note of this book for me is Jordan's continued use of the term 'nonprofessional' to describe those staff members without professional library qualifications. Although this label is still used, it is quite patronising, negative, and fails to convey a clear picture of the important responsibilities and duties many support staff now undertake. As many of the professional librarians using this book will have contact with, if not responsibility for, the support staff in their library and information services it is unfortunate that the term 'non-professional', with its connotations of inadequacy, is used here.

That aside, this remains an excellent and invaluable companion for any library worker, of whatever level, who supervises others, and will, rightly, continue to be the definitive text in this area for students of information and library studies.

\section{References}

1. Brenda White Associates. Education and recruitment of junior professionals: a study in the library and information profession. London: British Library Research and Development Department, 1989.

2. Harris, R. Librarianship: the erosion of a woman's profession. Norwood, N.J.: Ablex, 1992.

\section{Hopkins, Tracy}

User education in academic libraries. results of 1995 CTILIS Survey. An occasional publication published by the CIT Centre for Library and Information Studies. Loughborough: CTI Centre for Information and Library Studies, Loughborough University, 1995. $£ 5.00$ (ISBN 095266181 0).

Marianne Dee,

Education Tutor Librarian,

Leeds Metropolitan University

This is a small research report focusing on user education and the use of computer-based training (CBT) packages. Te research aims to establish if CBT packs have a valid place in user education and the report is intended to offer "a general overview of user education in 1995".

The report is in fact a very brief analysis of a small questionnaire which was circulated to libraries in 1995. It is certainly only an overview which is published and it stands in isolation from any previous work in the field, bar the odd reference and (in my opinion) disturbingly commonplace statements which have been used as quotes. Hopkins makes reference to previous writers in the field but a full literature review would have grounded the research in some firm foundations as well as acting as a contrast to the changes taking place in higher education today.

The results of the survey are reported in a fractional way so that any whole institutional response is broken up into parts which fit the categories 'standard' 'individual' and 'both' for example. These categories are intended to describe the type of education programme used by each library. Again quotes are taken out of institution's whole responses and blocked into groups of quotes which act as descriptors helping to shape a large part of the reports' final picture. One is left with what feels like anecdotal evidence shaping our view of reality. 
I would have also liked to see a definition of academic libraries and some analysis of those libraries which replied; for example the appendices illustrates that 31 London libraries replied and 7 Sheffield libraries, and this kind of geographical skew may or may not have affected the results. The overall picture which comes across is familiar and in some ways reassuring. This picture indicates the importance of contextualising the skills for students. The strength in strong liaison with academic staff which not only supports context but also ensures an enthusiasm and commitment to the skills; and the need for evaluation and assessment to be built in so that the student takes the input seriously, understands its relevance and also values it.

The report is a simple starting point which appears to illustrate our current state of play. However what is really needed is an up to date literature review and a robust research project which aims to provide in-depth evidence of good, bad and indifferent practice.

\title{
Muirhead, Graeme, ed.
}

The systems librarian: the role of the library systems manager. London: Library Association, 1994. $£ 35.00$. (ISBN 1-85604-116-6).

\author{
Ian R. Murray \\ Department of Information and Library Studies \\ Loughborough University
}

This volume is a much overdue analysis of the post of "systems librarian" within libraries and information centres. The book features contributions from both systems librarians, librarians and systems suppliers, thereby giving a variety of perspectives on the wider issue of how to manage Information Technology within the information and library sector. Therein, I believe, lies its greatest value because it is made clear that the post of systems librarian, plus the associated functions that have to be carried out with the managing of IT services, have an impact upon all services within the medium to large library. This alone makes the book essential reading for anyone concerned with managing IT within a library environment.

The book is divided into four parts, with an introduction by the editor which gives a brief overview of the contents. The sections are devoted to the role of the systems librarian; alternatives to the systems librarian; education and training; and the future. The contributions vary considerably in their style and content, with the most analytic chapters being contributed by Graeme Muirhead, where he concentrates on providing an analysis of the outcomes of a survey, conducted in the early $90 \mathrm{~s}$, on the role of the systems librarian. Other contributions which provide interesting insights into the complex world of the systems librarian are provided by Duncan Westlake and Gordon Dunsire. In particular, their contributions show how the post is constantly caught up in the flux of both technological and political change. Throughout the volume questions are raised, for example, what constitutes being a systems librarian? What skills do they require that other librarians do not possess? How should they be trained? These questions among others form a debate that is carried forward throughout the volume that is both lucid and interesting, and of relevance to all students and members of the profession.

Three areas struck me as important. In the first instance for the pure researcher, the substance of the book is contained in the chapters by Muirhead, some of which has already been published elsewhere ${ }^{(1,2)}$, with some further contributions in the section on education and training also 
grounded on research or practical experience. This means that whilst valuable, some of the other chapters do not have a research orientation. For example, there are some reflections on what it is like to be a "systems librarian". Secondly, it is as well to bear in mind that IT has not merely brought about major changes to the services provided, but also that it develops as well, becoming more userfriendly, and that overall there is an increasing number of people who are computer literate. Accordingly, the unique position of the systems librarian is vulnerable - the future, as Muirhead suggests is constantly evolving, with the possibility that all librarians will become systems librarians. This means that like any publication which is IT related there is bound to be some material which will become dated quite quickly. This leads onto my third point, which is that I felt that more comment regarding the future of the post and its place within the profession would have been welcome. Some areas touched on that I would have liked explored further was the general profile of the post, described as a "low" in terms of visibility within the profession. Why should this be so? What are the consequences? One such consequence might be for example, the recognised vulnerability of the position, threatened as it is by technological and political change.

This is a very well produced book which raises important questions and fills a gap in the literature. It has covered what it has been like to be a systems librarian through the late eighties and early nineties. With regard to what it is going to be like in the mid-nineties and into the next century I would look forward eagerly to a future edition.

\section{References}

1. Journal of Librarianship and Information Science, 25 (3), 1993, 123-135.

2. The Electronic Library, 11 (2), 1994, 97-107.

\section{Harris, Colin (Ed)}

The new university library: issues for the 90s and beyond: essays in honour of Ian Rogerson. London, Taylor Graham, 1994. £25.00 ( ISBN 094756864 6).

\section{J. Eric Davies}

Loughborough University

It falls to few people to have a whole anthology of writings assembled in their honour but this fitting tribute to Ian Rogerson, accomplished academic librarian and for twenty one years Librarian at Manchester Polytechnic (now Manchester Metropolitan University), is one such example. If the measure of his standing is reflected in the quality of the contributions for this work then it is high indeed and gives ample endorsement to Vice-Chancellor, Sir Kenneth Green's praise (in the foreword) to Ian's "... professionalism, imaginativeness, determination and energy ...."

Moreover, from the LIRN readership's viewpoint, it is not only quality but inspiration which emanates from between the covers of this work. It abounds with ideas and information for the researcher and practitioner alike.

In addition to the foreword by Sir Kenneth Green and an introduction by Colin Harris, there are eleven essays in this collection. They cover a broad canvas of professional interest from collection building to strategic planning but are "tied" together by the career and personality of the man they honour. 
F W Ratcliffe's Collections, collectors and collection building provides a spirited justification of organised and systematic collection building at a time when he concedes that, "It is hardly flavour of the library month ...." With several pertinent examples he reminds us of how much we owe the collection builders of the past and the way in which they have enriched scholarship. By no means, however, are we given a manifesto for unbridled and indiscriminate accumulation.

John Feather's Special collections in the university library brings a modern post-Follett outlook to bear on the management and utilisation of special collections. Change agents such as the expansion and diversity of higher education and the consequent variety of approaches to research, together with the digitisation of information, are identified as factors which require appropriate reactions from those who care for special collections.

"....as academics and students become more accustomed to using information services and systems which are independent of the library building, the provision of materials and services in that building will need to be even more sharply focused if it is to be justified in terms of the capital which it employs and the running costs which it incurs."

Preservation and access (but not necessarily physical access) are discussed at length and the need for strategies which recognise (as Follett did) the national and regional importance of some collections is also considered. Feather also notes that the electronically processed research material of today will itself be a candidate for special treatment in future.

Margaret Kinnell's Exploring small worlds in special collections of early children's books demonstrates the range and depth of her expertise in this area. She notes the growth of scholarly interest in the genre by a variety of specialists who recognise the value of literature for children and young people in revealing not only literary but cultural factors. Several important collectors and significant examples of children's publishing are discussed. Questions of access and preservation together with the role of catalogues for identifying what is available are addressed. A concluding section looks at the future development of research collections of children's books and expects it to continue to be "random in scope, coverage, and exploitation ..." as in the past unless her urgent plea for cooperation and organisation is heeded.

John Blunden-Ellis discusses the potential and mechanisms of library cooperation with reference to the Manchester experience in establishing a consortium of five academic libraries in: Looking for the future: The Consortium of Academic Libraries in Manchester (CALIM).

The planning, formation, development and future of the consortium, whose components have a combined budget of over $£ 11$ million, in excess of 350 staff and a user population exceeding 40,000 , are covered. Crucial elements and key factors to successful collaboration between institutions, which are at the same time competing at the institutional level and cooperating at a service level, are discussed.

Another aspect of collaboration and coordination, this time within an institution, and progressing towards integration in many instances, is considered by A G Williams in: Where are we going? The development of convergence between university libraries and computing services.

The increasing digitisation and networking of information has tended to dissolve the boundaries between computing and library services (and even other service units). In many institutions 
convergence has been the rational (if not fashionable) outcome. In an excellent and informed overview which draws on numerous sources, Williams first explores the American genesis of the concept and then discusses the British experience to date. Individual factors and features which influence the shape and outcome of convergence are discussed in detail. He reassuringly (for some) concludes that "University libraries will be with us for a long time yet!"

The new university librarian by David House and Christine Moon explores the roles and qualities of those who are and will be working at the information interface in the academic environment (real or virtual). Drawing for elucidation and inspiration on the several key reports on the sector which have appeared of late - Follett, Fielden, Fender (it seems mandatory to have to have a Chairman whose name begins with ' $F$ ') they paint a picture which is positive in terms of the excitement and interest which faces the professional but less in terms of the resources (and rewards) available. The changes brought about by electronic information and new service configurations such as convergence are discussed as are the management and leadership skills which are demanded.

But skills, qualities, commitment and even professionalism are one thing. Others' perceptions of us and what we do, and our own self-worth are quite another. In: The Image of the academic librarian: an analysis of the implications for the future through a study of the literature, Jeremy Atkinson reflects on how others see us and how we see ourselves in what is an extensive review of published material. That there are negative images is undisputed but the paper also explores the more positive aspects of librarians' work and worth and concludes with some pointers for changing things for the better.

Peter Jordan in Shouting and interpersonal skills training contrasts the intuitive, "born of experience" style of management with the more systematic and scientific approach of human resources management. One harbours a lingering admiration for Ian Rogerson, whose suspicion of management theories as "...flavours of the month - which would quickly be succeeded by something else and could usually be ignored" is noted by Peter Jordan, who then goes on to illustrate very convincingly the value of interpersonal skills, techniques and theories for helping people manage themselves and others.

One cannot but help conclude that it is not management theories that are lacking but often people's imagination and flexibility in applying them intelligently. To the extent that theories, any theories should not be adopted slavishly, Ian Rogerson was/is right!

To take a topical example, there is the buffoonery of proclaiming "downsizing" as the universal managerial alchemy to transmute stagnation into success. On offer is the prospect of fitter, leaner, meaner, (nastier?), organisations. But suddenly we are told that, perhaps, this is not such a clever concept after all; it is not the panacea we were all promised.( It is as if on the road to Damascus some managerial revelation had erupted.) In the wake of these events we contemplate the prospect of indifferent corporate performance, disenchanted customers, demotivated workforces, and blighted careers and wonder at the temerity of managerial soothsayers!

No matter how well organised and managed the institution, sometimes the unexpected happens. Disaster control planning: a review and case study by Lynn Elliott looks at how to deal with the major happenings that significantly disrupt and even threaten the viability of a library. After much neglect this area has recently begun to receive the serious study that it deserves. 
C J Hunt takes a historical overview of library planning and provision in The library buildings of the University of Manchester. He notes how even in these days of the "virtual" library, library buildings are thought of as something special and significant (perhaps because they cost so much!) - "The concept of the library as a monument, a physical manifestation of the idea of the university, an expression of pride and confidence in good teaching and learning, has always been fundamental in the building of academic libraries."

The final contribution by Peter Jackson The creation of a polytechnic library describes: "How did the Library of the Manchester Metropolitan University get from there to here, from being a group of three disparate college libraries in 1972 to being one of the larger university library systems in the country today?" It charts the evolution of the library service under Ian Rogerson's leadership. It really rounds off a fitting tribute to his energy and vision. 